Jurnal Tamwil: Jurnal Ekonomi Islam
http://ecampus.iainbatusangkar.ac.id/ojs/index.php/tamwil/index

\title{
PENGARUH PELATIHAN DAN PEMBERDAYAAN TERHADAP KINERJA PEGAWAI YANG DIMEDIASI OLEH KOMPETENSI
}

\author{
Arief Purwanto $^{1 *}$, Gatot Nugroho ${ }^{2}$ \\ Pascasarjana Universitas Widyagama Malang \\ Korespondensi: Jl. Taman Borobudur Barat No.35, Mojolangu, Kec. Lowokwaru, Kota Malang, Jawa Timur 65146 \\ e-mail: ariefpurwanto@widyagama.ac.id \\ *) Corresponding Author
}

\begin{abstract}
Abstrak: Artikel ini bertujuan menjelaskan pengaruh secara langsung variabel pelatihan, pemberdayaan, kompetensi, dan kinerja. Serta peran variabel mediasi kompetensi. Metode yang digunakan kuantitatif - ekpanatory. Populasi dan sampel adalah 54 responden. Pengumpulan data menggunakan kuesioner. Analisis data menggunakan smart-PLS 3. Hasil penelitian menunjukkan secara langsung bahwa pelatihan belum mampu meningkatkan kinerja pegawai. Sedangkan, pemberdayaan mampu meningkatkan kinerja pegawai, begitu juga dengan kompetensi mampu meningkatkan kinerja. Pada hasil penelitian secara tidak langsung, pertama diketahui bahwa kompetensi secara full mediation mampu memediasi pengaruh pelatihan terhadap kinerja pegawai. Kedua, kompetensi secara partial mediation mampu memediasi pengaruh pemberdayaan terhadap kinerja pegawai.
\end{abstract}

Kata Kucni: Pelatihan, Pemberdayaan, Kompetensi, Kinerja Karyawan

\begin{abstract}
This article aims to explain the direct influence of the variables of training, empowerment, competence, and performance. And the role of competence mediating variables. The method used is quantitative-explanatory. The population and sample are 54 respondents. They are collecting data using a questionnaire-data analysis using smart-PLS 3. The results show directly that training has not been able to improve employee performance. Meanwhile, empowerment can improve employee performance, as well as competence, can improve performance. In the indirect research results, first, it is known that competence in complete mediation can mediate the effect of training on employee performance. Second, competence in partial mediation can intervene in the influence of empowerment on employee performance.
\end{abstract}

Keywords: Training, Empowerment, Competence, Employee Performance

\section{PENDAHULUAN}

Kinerja adalah hasil kerja secara kualitas dan kuantitas yang dicapai oleh seseorang karyawan dalam melaksanakan tugasnya sesuai dengan tanggung jawab yang diberikan kepadanya (Moeheriono 2012). Agar dapat meningkatnya kinerja diperlukan kuantitas, kualitas, dan ketepatan waktu (Arfan, 2013).
Kinerja juga tidak lepas dari adanya pemberdayaan dan juga pelatihan.

Pelatihan secara singkat dapat didefinisikan salah satu usaha dalam meningkatkan mutu sumber daya manusia dalam dunia kerja (Dessler, 2010). Arfan (2013) menjelaskan bentuk dari pelatihan terdiri dari materi yang dibutuhkan, kemampuan instruktur pelatihan dan peserta 
pelatihan. Selain pelatihan guna meningkatkan kinerja, tidak kalah pentingnya dari sebuah pemberdayaan.

Pemberdayaan adalah bentuk implikasi dari pengembangan bagi bawahan (Sedarmayanti, 2014). Pemberdayaan berkaitan dengan Keberartian, Keyakinan diri, Penentuan diri, dan Dampak (Debora, 2006). Selain pemberdayaan terdapat juga pelatihan.

Hasil penelitian sebelumnya, bahwa pengaruh pelatihan terhadap kinerja yang dilakukan oleh Turere (2013); Rudhaliawan dkk (2012); Waris dan A (2015) memiliki pengaruh signifikan. Namun pada penelitian Pakpahan (2014) secara uji silmutan pelatihan berpengaruh positif terhadap kinerja, akan tetapi bila dilihat dari uji parsial pelatihan tidak berpengaruh terhadap kinerja. Hal ini muncul karena adanya inkonsistensian dari hasil penelitian sebelumnya sehingga terdapat gap research pada pengaruh pelatihan terhadap kinerja. Lantas, pengaruh pemberdayaan terhadap kinerja yang dilakukan oleh Heriyawan dan Setyowati (2015); Rahayu dan Rozak (2015); dan Huntsman, et al. (2021) memiliki pengaruh signifikan. Namun pada penelitian Ayuningtyas \& Djastuti (2017) menunjukkan bahwa pemberdayaan belum mampu meningkatkan kinerja. Hal ini muncul karena adanya inkonsistensian dari hasil penelitian sebelumnya sehingga terdapat gap research pada pengaruh pemberdayaan terhadap kinerja.

Dari penjelasan diatas, dapat diartikan bahwa belum banyak peneliti atau jarang peneliti lainnya mengungkap kompetensi sebagai variabel mediasi. Oleh sebab itu, penelitian saat ini adalah mengetahui peran kompetensi sebagai variabel mediasi.

Kompetensi adalah karakteristik yang dibutuhkan oleh seorang pemegang jabatan agar dapat melaksanakan jabatan dengan baik, atau juga dapat berarti karakteristik/ciri-ciri seseorang yang mudah dilihat termasuk pengetahuan, keahlian, dan perilaku yang memungkinkan untuk berkinerja (Byars dan Rue, 1997). Kompetensi dapat berupa Taske skills, Task management skills, Contingency management skills, Job role environment skills, dan Transfer skills (Moeheriono, 2012).
Penelitian sebelumnya, Winanti (2012) menyimpulkan bahwa kompetensi memiliki pengaruh yang positif dan signifikan terhadap kinerja karyawan. Artinya kompetensi karyawan menstimulir optimasi pembentukan kinerja karyawan dalam bekerja. Temuan ini relevan dengan pernyataan yang dikemukakan oleh Spencer \& Spencer (1993) bahwa kompetensi intelektual, emosional dan sosial sebagai bagian dari kepribadian yang paling dalam pada seseorang dapat memprediksi atau mempengaruhi keefektifan kinerja individu.

Pramularso (2018) temuan bahwa kompetensi memiliki hubungan pengaruh terhadap profesionalisme dan profesionalisme memiliki hubungan pengaruh terhadap kinerja dosen. Variabel kompetensi secara langsung memiliki hubungan pengaruh terhadap kinerja dosen.

Penelitian ini fokus untuk melihat pengaruh pelatihan dan pemberdayaan guna meningkatkan kinerja serta kompetensi pada BPBD Kota Batu. Masalah penelitian ini adalah bagaimana pelatihan mampu meningkatkan kinerja, bagaimana pemberdayaan mampu meningkatkan kinerja, dan peran kompetensi sebagai mediasi antara pelatihan, pemberdayaan, dan kinerja.

Sebelum menuliskan tujuan, penulis harus memaparkan latar belakang dan penelitian-penelitian terkait secara memadai untuk merekam solusi atau metode yang ada, untuk menunjukkan hal-hal terbaik yang telah dilakukan oleh para peneliti terdahulu, kelemahan-kelemahan yang dimiliki, serta halhal baru yang dihasilkan lewat penelitian yang Anda lakukan. Hindari membuat ringkasan terhadap hasil penelitian.

\section{METODE}

Penelitian ini menggunakan rancangan penelitian kuantitatif. Penelitian kuantitatif mengharuskan peneliti untuk menjelaskan bagaimana variabel mempengaruhi variabel yang lain (Creswell, 2014). Jenis penelitian ini adalah ekplanatory. Penelitian eksplanatori adalah menjelaskan hubungan sebab akibat dari beberapa variabel melalui pengujian hipotesis (Sekaran dan Bougie, 2017). 
Lokasi penelitian adalah tempat sumber data yang dianggap sebagai suatu populasi sehingga dapat diambil subyek yang diteliti. Penelitian ini dilakukan di Badan Penanggulangan Bencana Daerah (BPBD) Kota Batu yang terletak di Balai Kota Among Tani Blok B Lantai 1 JL P.B. Sudirman No. 507 Kec Batu, Kota Batu Jawa Timur 65311.

Populasi adalah suatu kelompok individu yang memiliki persamaan karakteristik (Creswell, 2014). Populasi penelitian ini adalah Pegawai Badan Penanggulangan Bencana Daerah (BPBD) Kota Batu. Sampel sebagian dari jumlah dan karakteristik yang dimiliki oleh populasi tersebut (Creswell, 2014). Teknik Sampel yang digunakan penelitian ini adalah Non-probabilistik Sampling berjenis purposive sampling dan sampel jenuh.

Purposive sampling adalah teknik penentuan sampel dengan pertimbangan tertentu yang memiliki kriteria sebagai berikut: PNS $=22$ Orang, Tenaga Honorer $=6$ Orang dan Tenaga Harian Lepas 26 Orang. Sampel yang diambil adalah sampel jenuh. Sampel jenuh (sensus) merupakan teknik penentuan sampel, bila semua anggota populasi digunakan sebagai sampel. Berdasarkan uraian tersebut, maka sampel yang diambil sejumlah 54 Pegawai Badan Penanggulangan Bencana Daerah (BPBD) Kota Batu.

Sumber data yang digunakan yakni berupa data primer dan data sekunder. Data primer dalam penelitian ini berupa hasil kuesioner, sedangkan data sekunder yang digunakan berupa jumlah, nama, umur pegawai dan lain-lain.

Analisis data pada penelitian ini adalah PLS (Partial Least Square) yaitu SEM yang berbasis komponen atau varian. PLS merupakan pendekatan alternatif yang bergeser dari pendekatan SEM berbasis kovarian menjadi berbasis varian (Ghozali dan Latan, 2015).

\section{HASIL DAN PEMBAHASAN}

Karakteristik responden ditinjau dari jenis kelamin pegawai laki-laki sejumlah 81\%. Lebih lanjut, ditinjau dari usia menunjukkan bahwa pegawai BPBD Kota Batu yang berusia 20-39 tahun, sebanyak 19 pegawai (35\%) memiliki usia yang produktif dan cenderung antusias, progresif, serta kreatif. Bila, ditinjau dari pendidikan menunjukkan bahwa pegawai dengan tingkat pendidikan S1 sebesar 54\%, disusul dengan pendidikan SMA sebesar 37\%, dan pendidikan S2 sebesar 9\%. Hal ini menunjukkan bahwa pegawai BPBD Kota Batu dengan tingkat pendidikan sarjana yang lebih banyak, yang menunjukkan bahwa ditingkat kedinasan sudah mengikuti aturan yang berlaku bahwa minimal S1. Jika, ditinjau dari golongan kepangkatan pegawai, sebesar 32 $(59 \%)$ menunjukkan bahwa pegawai BPBD Kota Batu belum memiliki golongan. Hal ini menunjukkan bahwa pegawai BPBD Kota Batu baik lama maupun baru masih berstatus tenaga outsourcing.

\section{Hasil Evaluasi Outer Model}

Convergent validity pada model pengukuran dapat dilihat melalui nilai outer loading pada hasil analisis. suatu item pengukuran dikatakan valid karena memiliki nilai koefisien lebih dari 0,7 .

Nilai AVE pada seluruh variabel menunjukkan lebih dari 0.50 , kemudian pada nilai $\sqrt{ }$ AVE seluruh variabel juga lebih besar daripada nilai korelasi antar variabel. Sehingga, dapat disimpulkan bahwa seluruh konstruk pada penelitian ini berdasarkan kriteria discriminant validity memiliki nilai yang baik.

Nilai composite reliability dan cronbach's alpha dari semua variabel laten dalam penelitian ini mempunyai nilai lebih dari 0,70, sehingga dapat dikatakan bahwa seluruh variabel pada penelitian ini reliabel.

\section{Hasil Evaluasi Inner Model}

Nilai R-Square pada kinerja pegawai 0.642, nili tersebut dapat diartikan bahwa kinerja pegawai mampu dijelaskan pelatihan, pemberdayaan, dan kompetensi sebesar $64.2 \%$ dan sisanya sebesar $35.8 \%$ dijelaskan variabel lain di luar model penelitian. Nilai R-Square untuk kompetensi sebesar 0.457 , nilai tersebut dapat diartikan bahwa kompetensi mampu dijelaskan pelatihan dan pemberdayaan sebesar $45.7 \%$ dan sisanya sebesar $54.3 \%$ dijelaskan variabel di luar model penelitian.

Q-Square predictive relevance digunakan untuk mengukur seberapa baik nilai observasi yang dilakukan sehingga dapat memberikan

Pengaruh Pelatihan Dan Pemberdayaan ... $\mid 3$ 
hasil terhadap model penelitian. Nilai Q-Square berkisar $0<\mathrm{Q}^{2}<1$, dengan nilai $\mathrm{R}$-Square yang telah diketahui maka dapat dihitung Q-Square predictive relevance dengan formula sebagai berikut:

$$
\begin{aligned}
\mathrm{Q}^{2} & =1-\left(1-\mathrm{R}^{2}{ }_{1}\right) \times\left(1-\mathrm{R}^{2}{ }_{2}\right) \\
& =1-(1-0.642) \times(1-0.457) \\
& =0.806
\end{aligned}
$$

Hasil perhitungan tersebut dapat ditunjukkan bahwa $\mathrm{Q}^{2}$ bernilai sebesar 0.806. Nilai tersebut menunjukkan bahwa keberagaman data yang dihasilkan dari model struktural yang diteliti dalam penelitian ini sangat baik karena mendekati nilai 1 .

\section{Pembahasan \\ Pengaruh Pelatihan Terhadap Kinerja}

Hasil penelitian menunjukkan bahwa pelatihan belum mampu meningkatkan kinerja pegawai BPBD Kota Batu. Hal ini dapat diartikan bahwa pelatihan tidak dapat secara langsung meningkatkan kinerja pegawai BPBD Kota Batu. Penyebab tidak berpengaruhnya pelatihan terhadap kinerja pegawai BPBD Kota Batu adalah kurangnya program pelatihan yang dilakukan pihak BPBD Kota Batu secara rutin. Pelatihan saat ini fokus pada tanggung jawab pegawai, hal ini berkaitan dengan seberapa efektif dan efisien dalam menyelesaikan tugas yang diberikan kepada masing-masing pegawai di BPBD Kota Batu. Hal ini dibuktikan dengan banyaknya pria direntan usia 20-39 memiliki usia yang produktif dan cenderung antusias, progresif, serta kreatif, sehingga tanggung jawab pekerjaan harus dapat terselesaikan dengan tepat waktu. Bila dilihat dari deskripsi jawaban responden item terendah terletak pada tanggung jawab pegawai. Hal ini menunjukkan bahwa pelatihan yang membutuhkan pelatih khusus untuk meningkatkan kemampuan dapat mengundang pemateri-pemateri yang profesional dalam melakukan kegiatan program pelatihan.

Pelatihan merupakan bagian dari investasi SDM (buman investment) untuk meningkatkan kemampuan dan keterampilan kerja, dan dengan demikian meningkatkan kinerja pegawai (Simanjuntak, 2005). Hasil penelitian ini mendukung temuan dari Pakpahan (2014) menyatakan bahwa secara parsial pelatihan tidak berpengaruh signifikan terhadap kinerja pegawai. Adapun dari Naqvi dan Khan (2013) menemukan bahwa pelatihan karyawan belum mampu meningkatkan kinerja karyawan.

\section{Pengaruh Pemberdayaan Terhadap Kinerja}

Hasil analisis membuktikan bahwa pemberdayaan mampu meningkatkan kinerja pegawai BPBD Kota Batu. Hal ini dapat diartikan bahwa pemberdayaan yang dimiliki oleh pegawai BPBD Kota Batu seperti keberartian diri, keyakinan diri, penentuan diri, dan dampaknya dapat memberikan kontribusi pada kinerja pegawai BPBD Kota Batu yang berkaitan dengan kuantitas, kualitas, dan ketepatan waktu dalam bekerja. Hal ini ditunjukkan pada karakteristik responden yang di dominasi oleh laki-laki dan usia produktif direntan usia 20-39 memiliki kecenderung antusias, progresif, serta kreatif dalam bekerja. Bila dilihat dari deskripsi jawaban responden pada variabel pemberdayaan, item tertinggi adalah menentukan sasaran yang bermakna. $\mathrm{Hal}$ ini mengindikasikan bahwa setiap pekerjaan yang dilakukan oleh pegawai BPBD Kota Batu memiliki keberartian.

Secara teori mendukung, Sedarmayanti (2014) mengemukakan bahwa: "Pemberdayaan merupakan salah satu upaya yang wajib dilakukan bagi terciptanya sumber daya manusia yang berkualitas, memiliki kemampuan memanfaatkan, mengembangkan dan menguasai ilmu pengetahuan dan tekhnologi serta kemampuan menajemen". Hasil penelitian ini juga mendukung temuan dari Heriyawan dan Setyowati (2015) menunjukkan bahwa karakteristik pekerjaan berpengaruh positif dan signifikan terhadap komitmen organisasi. Pemberdayaan berpengaruh positif dan signifikan terhadap komitmen organisasi, Karakteristik Pekerjaan berpengaruh positif namun tidak signifikan terhadap kinerja karyawan, Pemberdayaan berpengaruh positif dan signifikan terhadap kinerja karyawan, sedangkan Komitmen Organisasi berpengaruh positif dan signifikan terhadap kinerja karyawan.

Rahayu dan Rozak (2015) menunjukkan bahwa Kepribadian berpengaruh positif dan 
signifikan terhadap OCB, Pemberdayaan berpengaruh positif dan signifikan terhadap OCB, Kepribadian berpengaruh positif dan signifikan terhadap kinerja pegawai, Pemberdayaan berpengaruh positif dan signifikan terhadap kinerja, OCB berpengaruh positif dan signifikan terhadap kinerja pegawai, Kepribadian tidak berpengaruh positif dan signifikan terhadap kinerja, Pemberdayaan berpengaruh positif dan signifikan terhadap kinerja, OCB tidak berpengaruh positif dan signifikan terhadap kinerja, Hasil uji mediasi menunjukkan bahwa OCB memediasi pengaruh pemberdayaan terhadap kinerja pegawai, namun OCB tidak memediasi pengaruh kepribadian terhadap kinerja pegawai. Hasil uji moderasi menunjukkan bahwa modal sosial tepat digunakan sebagai variabel moderating, yang berperan memoderasi hubungan antara pemberdayaan dengan kinerja pegawai.

Huntsman, et al. (2021) menunjukkan bahwa pemberdayaan praktik meningkatkan kinerja adaptif dengan membantu petugas pemadam kebakaran menanggapi aspek tak terduga dari pekerjaan mereka. Selain itu, keseimbangan tempo memoderasi peluang pengembangan karir, otonomi kerja, dan kinerja adaptif, khususnya.

\section{Pengaruh Pelatihan Terhadap Kompetensi}

Hasil penelitian menunjukkan bahwa pelatihan mampu meningkatkan kompetensi pegawai BPBD Kota Batu. Hal ini dapat diartikan bahwa pelatihan yang dilaksanakan oleh pihak lembaga, nantinya akan dapat meningkatkan kompetensi setiap pegawai. Hal ini dapat ditunjukkan dengan karakteristik responden yang lebih banyak laki-laki yang berusia 20-39 memiliki kecenderung antusias, progresif, serta kreatif dalam bekerja dan dapat melakukan upgrading kompetensi yang dimiliki dengan mengikuti pelatihan. Bila dilihat dari deskripsi jawaban responden pada variabel pelatihan, item tertinggi materi keterampilan. Artinya, bahwa pelatihan yang memiliki indikator materi yang dibutuhkan sangatlah penting guna dapat meningkatkan kompetensi pegawai BPBD Kota Batu

Secara teori mendukung teori pelatihan, dimana pelatihan didefinisikan sebagai berbagai usaha pengenalan untuk mengembangkan kinerja tenaga kerja pada pekerjaan yang dipikulnya atau juga sesuatu berkaitan dengan pekerjaannya. Hal ini biasanya berarti melakukan perubahan perilaku, sikap, keahlian, dan pengetahuan yang khusus atau spesifik (Bernardin dan Russell, 1998).

Hasil ini juga mendukung temuan Saraswati (2015) menyimpulkan bahwa pengaruh pelatihan terhadap kompetensi ditunjukkan dengan semakin sering karyawan mengikuti pelatihan maka semakin tinggi tingkat kompetensi yang dimiliki oleh karyawan tersebut. Rudhaliawan dkk (2012) menyimpulkan bahwa terdapat pengaruh yang signifikan pelatihan terhadap kinerja dan terdapat pengaruh yang signifikan kemampuan kerja terhadap kinerja. Serta pelatihan akan mampu menaikkan kinerja melalui peningkatan kemampuan kerja. Waris dan A (2015) menunjukkan bahwa pelatihan, kompetensi, dan kinerja memiliki pengaruh terhadap kinerja. Lebih lanjut, secara parsial variabel pelatihan mampu meningkatkan kinerja karyawan, begitu juga dengan variabel kompetensi mampu meningkatkan kinerja karyawan, serta disiplin kerja miliki peran besar dalam meningkatkan kinerja karyawan.

\section{Pengaruh Pemberdayaan Terhadap Kompetensi}

Hasil analisis menunjukkan bahwa pemberdayaan mampu meningkatkan kompetensi pegawai BPBD Kota Batu. Artinya bahwa pemberdayaan yang meliputi keberartian diri, keyakinan diri, penentuan diri, dan dampaknya dapat menjadikan karyawan dapat Task skills, Task management skills, Contingency management skills, Job role environment skills, dan Transfer skills. Hal ini dapat ditunjukkan dengan pegawai laki-laki yang berusia 20-39 memiliki kecenderung antusias, progresif, serta kreatif dalam bekerja dan dapat melakukan upgrading kompetensi yang dimiliki dengan selalu ikutserta dalam kegiatan BPBD Kota Batu.

Secara teori kompetensi yang didukung oleh Task skills, Task management skills, Contingency management skills, Job role environment skills, dan Transfer skills (Moeheriono, 2012), 
mampu memberikan Personal Attribute: kompetensi intrinsik individu dan menghubungkan bagaimana orang berpikir, merasa, belajar, dan berkembang. Kompetensi ini meliputi integritas dan kejujuran, pengembangan diri, ketegasan, kualitas keputusan, manajemen stress, berpikir analitis, dan berpikir konseptual (Zwell, 2005).

Hasil ini sejalan dengan penelitian Sulistiasih (2019) menunjukkan bahwa kompetensi karyawan dapat ditingkatkan melalui pemberdayaan karyawan, seperti: memberi penguatan pada kompetensi karyawan; menciptakan budaya atau iklim organisasi yang memungkinkan kompetensi karyawan ditingkatkan secara optimal; memberikan dukungan penuh kepada karyawan sehingga mereka dapat melayani peran mereka dan mengaktualisasikan kompetensi mereka secara optimal; mendorong partisipasi dalam kegiatan organisasi; memberikan akses pada informasi seluas mungkin; mendorong pertumbuhan inovasi dengan memungkinkan dan memberi kesempatan untuk mengekspresikan setiap ide inovatif dan kreatif potensial yang dapat memperkaya kompetensi mereka; dan mendorong akuntabilitas yang tinggi. Penelitian Zebua (2020) menyatakan bahwa team building, pemberdayaan karyawan berpengaruh positif dan signifikan terhadap kompetensi karyawan.

\section{Pengaruh Kompetensi Terhadap Kinerja}

Hasil analisis menunjukkan bahwa kompetensi mampu meningkatkan kinerja pegawai BPBD Kota Batu. Hal ini dapat diketahui dari karakteristik responden, dimana usia berada di masa produktif kerja dan dapat meningkatkan kompetensinya untuk bisa berkinerja dengan baik. Hasil outer loading menunjukkan bahwa pegawai BPBD Kota Batu dapat beradaptasi dengan mudah di lingkungan yang berbeda, itu karena nilai yang terdapat di item tersebut memiliki nilai yang tinggi.

Winanti (2012) dalam penelitiannya menyimpulkan bahwa kompetensi memiliki pengaruh yang positif dan signifikan terhadap kinerja karyawan. Artinya kompetensi karyawan menstimulir optimasi pembentukan kinerja karyawan dalam bekerja. Temuan ini relevan dengan pernyataan yang dikemukakan oleh Spencer \& Spencer (1993) bahwa kompetensi intelektual, emosional dan sosial sebagai bagian dari kepribadian yang paling dalam pada seseorang dapat memprediksi atau mempengaruhi keefektifan kinerja individu. Pramularso (2018) temuan bahwa kompetensi memiliki hubungan pengaruh terhadap profesionalisme dan profesionalisme memiliki hubungan pengaruh terhadap kinerja dosen. Variabel kompetensi secara langsung memiliki hubungan pengaruh terhadap kinerja dosen.

\section{Pengaruh Pelatihan Terhadap Kinerja Melalui Kompetensi}

Hasil analisis membuktikan bahwa pelatihan berdampak penting bagi kinerja pegawai melalui kompetensi. Dampak mediasi kompetensi tersebut diketahui bersifat full mediation (mediasi penuh). Dengan demikian, dapat diartikan bahwa kompetensi dapat menjadi jembatan dari pengaruh pelatihan terhadap kinerja pegawai BPBD Kota Batu. Sejalan dengan Barry dan Kenny (1986) bahwa dalam variabel mediasi terdapat salah satu pembuktian intervensi variabel mediasi yang menyatakan bahwa jika (a) dan (b) signifikan, tetapi (c) tidak signifikan maka (c') dikatakan sebagai variabel mediasi penuh (full mediation). Dalam hal Dalam hal ini korelasi (a) menunjukkan model pemeriksaan pengaruh variabel independen terhadap variabel mediasi yaitu pengaruh pelatihan terhadap kompetensi, korelasi (b) menunjukkan pemeriksaan pengaruh variabel mediasi terhadap variabel dependen yaitu pengaruh kompetensi terhadap kinerja pegawai BPBD Kota Batu, dan korelasi (c) menunjukkan pemeriksaan pengaruh variabel independen terhadap variabel dependen secara langsung atau tanpa melalui variabel mediasi yaitu pengaruh pelatihan terhadap kinerja pegawai BPBD Kota Batu.

Hasil penelitian ini mendukung, penelitian dari Rudhaliawan dkk (2012) menyimpulkan bahwa terdapat pengaruh yang signifikan pelatihan terhadap kinerja dan terdapat pengaruh yang signifikan kemampuan kerja terhadap kinerja. Serta pelatihan akan mampu menaikkan kinerja melalui peningkatan kemampuan kerja. Penelitian 
Aditya (2015) menunjukkan Pelatihan yang diberikan kepada karyawan dapat mendorong para karyawan bekerja lebih giat, hal ini disebabkan karena karyawan akan berusaha mencapai prestasi kerja yang lebih tinggi. Dengan adanya program pelatihan diharapkan para karyawan dapat meningkatkan kompetensi karyawan dan kinerja karyawan untuk mencapai sasaran kerja yang telah ditetapkan oleh perusahaan. Pencapaian prestasi kerja yang baik haruslah diikuti oleh peningkatan kompetensi karyawan dan kinerja karyawan.

\section{Pengaruh Pemberdayaan Kinerja Melalui Kompetensi}

Terhadap

Hasil analisis membuktikan bahwa pemberdayaan berdampak penting bagi kinerja pegawai melalui kompetensi. Dampak mediasi kompetensi tersebut diketahui bersifat partial mediation (mediasi sebagian). Dengan demikian, dapat diartikan bahwa kompetensi dapat menjadi jembatan dari pengaruh pelatihan terhadap kinerja pegawai, akan tetapi tanpa adanya kompetensi pada dasarnya pemberdayaan mampu meningkatkan kinerja pegawai BPBD Kota Batu.

Sejalan dengan Barry dan Kenny (1986) bahwa dalam variabel mediasi terdapat salah satu pembuktian intervensi variabel mediasi yang menyatakan bahwa jika (a), (b), dan (c) signifikan maka (c') dikatakan sebagai variabel mediasi sebagian (partial mediation). Dalam hal Dalam hal ini korelasi (a) menunjukkan model pemeriksaan pengaruh variabel independen terhadap variabel mediasi yaitu pengaruh pemberdayaan terhadap kompetensi, korelasi (b) menunjukkan pemeriksaan pengaruh variabel mediasi terhadap variabel dependen yaitu pengaruh kompetensi terhadap kinerja pegawai BPBD Kota Batu, dan korelasi (c) menunjukkan pemeriksaan pengaruh variabel independen terhadap variabel dependen secara langsung atau tanpa melalui variabel mediasi yaitu pengaruh pemberdayaan terhadap kinerja pegawai BPBD Kota Batu.

Rahayu dan Rozak (2015) menunjukkan bahwa Kepribadian berpengaruh positif dan signifikan terhadap OCB, Pemberdayaan berpengaruh positif dan signifikan terhadap OCB, Kepribadian berpengaruh positif dan signifikan terhadap kinerja pegawai, Pemberdayaan berpengaruh positif dan signifikan terhadap kinerja, OCB berpengaruh positif dan signifikan terhadap kinerja pegawai, Kepribadian tidak berpengaruh positif dan signifikan terhadap kinerja, Pemberdayaan berpengaruh positif dan signifikan terhadap kinerja, OCB tidak berpengaruh positif dan signifikan terhadap kinerja, Hasil uji mediasi menunjukkan bahwa OCB memediasi pengaruh pemberdayaan terhadap kinerja pegawai, namun OCB tidak memediasi pengaruh kepribadian terhadap kinerja pegawai. Hasil uji moderasi menunjukkan bahwa modal sosial tepat digunakan sebagai variabel moderating, yang berperan memoderasi hubungan antara pemberdayaan dengan kinerja pegawai

Heriyawan dan Setyowati (2015) menunjukkan bahwa karakteristik pekerjaan berpengaruh positif dan signifikan terhadap komitmen organisasi. Pemberdayaan berpengaruh positif dan signifikan terhadap komitmen organisasi, Karakteristik Pekerjaan berpengaruh positif namun tidak signifikan terhadap kinerja karyawan, Pemberdayaan berpengaruh positif dan signifikan terhadap kinerja karyawan, sedangkan Komitmen Organisasi berpengaruh positif dan signifikan terhadap kinerja karyawan.

Pramularso (2018) temuan bahwa kompetensi memiliki hubungan pengaruh terhadap profesionalisme dan profesionalisme memiliki hubungan pengaruh terhadap kinerja dosen. Variabel kompetensi secara langsung memiliki hubungan pengaruh terhadap kinerja dosen. Winanti (2012) dalam penelitiannya menyimpulkan bahwa kompetensi memiliki pengaruh yang positif dan signifikan terhadap kinerja karyawan. Artinya kompetensi karyawan menstimulir optimasi pembentukan kinerja karyawan dalam bekerja. Temuan ini relevan dengan pernyataan yang dikemukakan oleh Spencer \& Spencer (1993) bahwa kompetensi intelektual, emosional dan sosial sebagai bagian dari kepribadian yang paling dalam pada seseorang dapat memprediksi atau mempengaruhi keefektifan kinerja individu. 


\section{KESIMPULAN}

Berdasarkan hasil penelitian disimpulkan secara parsial bahwa pelatihan belum mampu meningkatkan kinerja pegawai. Disisi lain, pelatihan mampu meningkatkan kompetensi pegawai. Selanjutnya, secara parsial pemberdayaan mampu meningkatkan kompetensi dan kinerja pegawai. Hasil penelitian secara tidak langsung menunjukkan bahwa kompetensi memliki dua sifat, dimana kompetensi memiliki sifat full mediation pada pelatihan terhadap kinerja pegawai. Disamping itu, kompetensi memiliki sifat parsial mediation pada pemberdayaan terhadap kinerja pegawai BPBD Kota Batu.

Hasil penelitian ini dapat dijadikan pertimbangan oleh pihak instansi perihal pengembangan kinerja pegawai BPBD Kota Batu dengan adanya program pelatihan yang diadakan secara rutin.

\section{DAFTAR KEPUSTAKAAN}

Aditya, R. (2015). Pengaruh pelatihan terhadap kompetensi dan kinerja karyawan (studi pada karyawan PT. PLN (Persero) distribusi Jawa Timur Area Malang). Jurnal Administrasi Bisnis, 27(2).

Arfan Aruan, D. (2013). Pengaruh pelatihan kerja dan motivasi terhadap kinerja karyawan PT. Sucofindo (persero) Surabaya. Jurnal Ilmu Manajemen (JIM), 1(2).

Ayuningtyas, A. H., \& Djastuti, I. 2017. Analisis Pengaruh Pemberdayaan Dan Pengembangan Karir Terhadap Kinerja Karyawan Dengan Kepuasan Kerja Sebagai Variabel Intervening (Studi pada Karyawan PDAM Tirta Moedal Kota Semarang). (Doctoral dissertation, Fakultas Ekonomika dan Bisnis).

Baron, R.M. and Kenny, D.A. 1986. The moderator-mediator variable distinction in social psychological research: Conceptual, strategic, and statistical considerations. Journal of Personality and Social Psychology. 51(6): 11731182.
Bernardin And Russell. 1998. Human Resource Management. Second Edition. Singapore. McGraw-Hill Book Co.

Byars dan Rue, 1997. Human Resource Management. 5th Edition. Chicag: McGrw-Hill Companies, Inc.

Creswell, J. W. 2014. Research Design: Qualitative, Quantitative and Mixed Methods Approaches: Fourth edition. Thousand Oaks, CA: Sage Publications.

Debora, 2006. Pengaruh Pemberdayaan Kerja dan Pemberdayaan Psikologis Terhadap Kepercayaan Organisasional dan Kepuasan Kerja (Studi Pada Dosen Tetap PTS Berbentuk Universitas Di Kalimantan). Disertasi. Program Doktor Ilmu Administrasi Bisnis. Malang. Universitas Brawijaya.

Dessler, Gary. 2013. Human Resources Management, Precentine Hall.

Ghozali, Imam, Hengky Latan. 2015. Konsep, Teknik, Aplikasi Menggunakan Smart PLS 3.0 Untuk Penelitian Empiris. BP Undip. Semarang.

Heriyawan, M. S., \& Setyowati, W. (2015). Pengaruh Karakteristik Pekerjaan Dan Pemberdayaan Terhadap Kinerja Pegawai Dengan Mediasi Komitmen Organisasional (Studi Pada Politeknik Ilmu Pelayaran Semarang).

Huntsman, D., Greer, A., Murphy, H., \& Haynes, S. (2021). Enhancing adaptive performance in emergency response: Empowerment practices and the moderating role of tempo balance. Safety Science, 134, 105060. doi:10.1016/j.ssci.2020.105060.

Moeheriono. 2012. "Pengukuran Kinerja Berbasis Kompetensi”. Jakarta: Raja Grafindo Persada.

Naqvi, S. M. H., \& Khan, M. A. (2013). Employees training and organizational performance: Mediation by employees performance. Institute of Interdisciplinary Business Research, 5(4), 490-503.

Pakpahan, E. S. (2014). Pengaruh Pendidikan dan Pelatihan terhadap Kinerja Pegawai (Studi pada Badan Kepegawaian Daerah Kota Malang). Jurnal Administrasi Publik, 2(1), 116-121. 
Pramularso, E. Y. (2018). Pengaruh Kompetensi terhadap Kinerja Karyawan CV Inaura Anugerah Jakarta.

Rahayu, S., \& Rozak, H. A. (2015). Pengaruh Kepribadian Dan Pemberdayaan Terhadap Kinerja Melalui Organizational Citizenship Behavior Dengan Modal Sosial Sebagai Variabel Moderating.

Rudhaliawan, V. M. (2013). Pengaruh Pelatihan terhadap Kemampuan Kerja dan Kinerja Karyawan (Studi pada Karyawan PT. Telkom Indonesia, Tbk Kandatel Malang). Jurnal Administrasi Bisnis, 4(2).

Saraswati, A. B. 2015. Pengaruh pelatihan terhadap kompetensi karyawan dan kualitas pelayanan (studi pada Eco Green Park, Batu). Jurnal Administrasi Bisnis, 24(1).

Sedarmayanti. 2014) Sumber Daya Manusia dan Produktivitas Kerja. Jakarta: Mandar Maju.

Sekaran, Uma dan Roger Bougie. 2017. Research Method for Business: A Skill Building Approach. John Wiley \& Sons. New York.

Simanjuntak, Payaman J. 2005. Manajemen dan Evaluasi Kerja. Lembaga Penerbit FEUI. Jakarta.

Spencer, Lyle \& Signe M. Spencer. 1993. Competence at Work, Models for Superior Performance. Canada: John Wiley \& Sons, Inc.
Sulistiasih, S. 2019. Strategi Pemberdayaan dalam Meningkatkan Kompetensi Karyawan Perusahaan Swasta. Ikra-Ith Ekonomika, 2(2), 73-78.

Turere, Nitta, Verra. 2013. Pengaruh Pendidikan dan Pelatihan terhadap Kinerja Pegawai pada Balai Pelatihan Teknis Pertanian Kalasey. Jurnal EMBA Vol. 1 No.3 (2013). Hal 10 - 19. ISSN 2303-1174.

Waris, A. P. M. dan A. 2015. Effect of Training, Competence and Discipline on Employee Performance in Company (Case Study in PT. Asuransi Bangun Askrida). Procedia - Social and Behavioral Sciences, 211, 1240-1251.

Winanti, Marliana Budhiningtias. 2011. Pengaruh Kompetensi terhadap Kinerja Karyawan (Survei pada PT. Frisian Flag Indonesia Wilayah Jawa Barat). Majalah Ilmiah Unikom, Vol.7 No.2. Bidang Humaniora.

Wirawan. 2009. Evaluasi Kinerja Sumber Daya Manusia Teori Aplikasi dan Penelitian. Jakarta. Penerbit: Salemba Empat.

Zebua, D. K. 2020. Pengaruh Team Building Dan Pemberdayaan Karyawan Terhadap Kompetensi Karyawan Pada Sekolah Tinggi Stie Sakti Alam Kerinci. Prosiding Simposium Nasional Magister (SINMAG), 4(1).

Zwell, Michael. 2000. Creating a Culture of Competence. New York: John Wiley \& Sons, Inc. 